\title{
Comparative visual function in four piscivorous fishes inhabiting Chesapeake Bay
}

\author{
AZ Horodysky \\ Virginia Institute of Marine Science
}

RW Brill

\section{EJ Warrant}

JA Musick

Virginia Institute of Marine Science

RJ Latour

Virginia Institute of Marine Science

Follow this and additional works at: https://scholarworks.wm.edu/vimsarticles

Part of the Aquaculture and Fisheries Commons

\section{Recommended Citation}

Horodysky, AZ; Brill, RW; Warrant, EJ; Musick, JA; and Latour, RJ, Comparative visual function in four piscivorous fishes inhabiting Chesapeake Bay (2010). Journal Of Experimental Biology, 213(10), 1751-1761.

10.1242/jeb.038117

This Article is brought to you for free and open access by the Virginia Institute of Marine Science at W\&M ScholarWorks. It has been accepted for inclusion in VIMS Articles by an authorized administrator of W\&M ScholarWorks. For more information, please contact scholarworks@wm.edu. 
The Journal of Experimental Biology 213, 1751-1761 (c) 2010. Published by The Company of Biologists Ltd doi:10.1242/jeb.038117

\title{
Comparative visual function in four piscivorous fishes inhabiting Chesapeake Bay
}

\author{
Andrij Z. Horodysky ${ }^{1, \star}$, Richard W. Brill ${ }^{2}$, Eric J. Warrant ${ }^{3}$, John A. Musick ${ }^{1}$ and Robert J. Latour ${ }^{1}$ \\ ${ }^{1}$ Department of Fisheries Science, Virginia Institute of Marine Science, College of William \& Mary, Rt 1208 Greate Road, \\ Gloucester Point, VA 23062, USA, ${ }^{2}$ Cooperative Marine Education and Research Program, Northeast Fisheries Science Center, \\ National Marine Fisheries Service, NOAA, Woods Hole, MA 02543, USA and ${ }^{3}$ Department of Cell and Organism Biology, \\ Vision Group, Lund University, Lund, Sweden \\ ${ }^{*}$ Author for correspondence at present address: Living Marine Resources Cooperative Science Center, Department of Marine and Environmental \\ Science, Hampton University, Hampton, VA 23668, USA (andrij.horodysky@ hamptonu.edu)
}

Accepted 1 February 2010

\begin{abstract}
SUMMARY
Maintaining optimal visual performance is a difficult task in photodynamic coastal and estuarine waters because of the unavoidable tradeoffs between luminous sensitivity and spatial and temporal resolution, yet the visual systems of coastal piscivores remain understudied despite differences in their ecomorphology and microhabitat use. We therefore used electroretinographic techniques to describe the light sensitivities, temporal properties and spectral sensitivities of the visual systems of four piscivorous fishes common to coastal and estuarine waters of the western North Atlantic: striped bass (Morone saxatilis), bluefish (Pomatomus saltatrix), summer flounder (Paralichthys dentatus) and cobia (Rachycentron canadum). Benthic summer flounder exhibited higher luminous sensitivity and broader dynamic range than the three pelagic foragers. The former were at the more sensitive end of an emerging continuum for coastal fishes. By contrast, pelagic species were comparatively less sensitive, but showed larger day-night differences, consistent with their use of diel light-variant photic habitats. Flicker fusion frequency experiments revealed significant interspecific differences at maximum intensities that correlated with lifestyle and habitat. Spectral responses of most species spanned $400-610 \mathrm{~nm}$, with significant day-night differences in striped bass and bluefish. Anadromous striped bass additionally responded to longer wavelengths, similar to many freshwater fishes. Collectively, these results suggest that pelagic piscivores are well adapted to bright photoclimates, which may be at odds with the modern state of eutrified coastal and estuarine waters that they utilize. Recent anthropogenic degradation of water quality in coastal environments, at a pace faster than the evolution of visual systems, may impede visually foraging piscivores, change selected prey, and eventually restructure ecosystems.
\end{abstract}

Key words: electroretinography, fish, flicker fusion frequency, spectral sensitivity, piscivore, visual ecology.

\section{INTRODUCTION}

Waters of different types differentially scatter and absorb downwelling light, affecting their spectral bandwidth (color) and intensity (brightness). Pure natural waters and clear pelagic seas maximally transmit short wavelength (blue) light, whereas coastal waters are most deeply penetrated by intermediate (green) wavelengths. Estuarine and many fresh waters maximally transmit longer (yellow-red) wavelengths due to increasing concentrations of phytoplankton, yellow products of vegetative decay (Gelbstoff), and suspended particulates that scatter, absorb and more rapidly attenuate light (Lythgoe, 1975; Lythgoe, 1988; Jerlov, 1968). Fishes have radiated into a wide range of aquatic photohabitats possessing complex photic properties, exposing their visual systems to a myriad of selective pressures (Levine and MacNichol, 1979; Collin, 1997). The visual systems of fishes have thus evolved to generally reflect the characteristics of aquatic light fields in their specific microhabitats and macrohabitats (Guthrie and Muntz, 1993).

Estuarine and near-coastal waters represent some of the most dynamic aquatic photohabitats on Earth. Luminous and chromatic properties of these waters vary on temporal and spatial scales ranging from milliseconds to decades, and millimeters to kilometers (e.g. Schubert et al., 2001; Harding, 1994). This extensive variability is due to vertical mixing, stratification, wave activity, clouds and weather, sunrise and sunset, seasonal solar irradiance, phytoplankton dynamics, as well as anthropogenically induced processes such as eutrophication and sedimentation (McFarland and Loew, 1983; Wing et al., 1993; Schubert et al., 2001; Gallegos et al., 2005; Kemp et al., 2005). Furthermore, at midday, a fixed point in an estuary can range widely in luminous and chromatic properties due to tidal and freshwater inputs along salinity gradients. Flood tides push relatively well-lit green coastal waters into estuaries, while falling ebb tides draw highly attenuating, very turbid riverine waters through the estuary and out to sea (e.g. Bowers and Brubaker, 2004).

The visual systems of fishes inhabiting highly productive and frequently turbid coastal waters must balance luminous sensitivity, resolution, contrast perception and rapid adaptation to dynamic light conditions depending on evolutionary pressures and phylogenetic constraints (Dartnall, 1975; Levine and MacNichol, 1979). The eyes of diurnal predatory fishes typically use rod photoreceptors during scotopic (dim/dark) conditions and cone photoreceptors under photopic (bright) conditions, the latter potentially differing in number, the pigments they contain, and their spectral position depending on phylogeny, species' lifestyle and optical microhabitat (Lythgoe, 1979; Crescitelli, 1991; Levine and MacNichol, 1979). At the cost of acuity, luminous sensitivity can be extended under dim conditions by widening pupils, increasing spatial and temporal summation, and even reradiating light through retinal media to maximize photon capture (Warrant, 1999). However, unavoidable tradeoffs between luminous sensitivity and resolution limit the 
plasticity of optical responses to widely ranging photic conditions (Warrant, 1999).

Many shallow-dwelling piscivores have large, broadly tuned and highly resolute eyes, foraging visually when light is not limiting because a wider breadth of information is rapidly available through this sensory channel relative to other modalities (Hobson et al., 1981; Guthrie and Muntz, 1993; Rowland, 1999). Paradoxically, many fishes that inhabit productive but turbid estuaries rely on vision to detect their predators, prey and mates (Abrahams and Kattenfield, 1997; Engström-Östa and Candolin, 2007). The visual range of fishes is constrained when the luminous and chromatic properties of light are limiting due to changing diel light conditions or via scattering and absorption by suspended materials. Degradation of optical conditions affects predators and prey asymmetrically. Mild turbidity may enhance prey contrast, but piscivory is inhibited under adverse optical conditions via the reduction of ambient light intensity and contrast degradation, with the ultimate effect of decreasing effective visual fields and increasing search time (Vogel and Beauchamp, 1999; Utne-Palm, 2002). Simultaneously, turbidity enhances cover and foraging opportunities for planktivorous species that are released from predation by piscivores [i.e. 'turbidity as cover hypothesis' (Gregory and Northcote, 1993)]. Piscivores may therefore be forced to abandon visual foraging for less-efficient encounter-rate feeding and to shift from pelagic to benthic prey when optical conditions are greatly degraded (Grecay and Targett, 1996a; Grecay and Targett, 1996b; De Robertis et al., 2003). Such foraging shifts may tip the competitive predatory balance in an ecosystem from visually feeding piscivores to tactile and chemoreceptive foragers, with potentially cascading effects (Carpenter and Kitchell, 1993; Aksnes and Utne, 1997). Additionally, degradation of the chromatic and luminous properties of light fields can affect the distribution and movements of predatory fishes (McFarland, 1986), interspecific and intraspecific communication (Siebeck et al., 2006), reproductive habits and speciation (Seehausen et al., 1997), as well as vulnerability to fishing gear (Loesch et al., 1982; Walsh, 1991; Buijse et al., 1992).

In summary, because predation by visually foraging piscivorous fishes can affect the structure and function of aquatic communities (Paine, 1966; Northcote, 1988), changes in the visual environment may thus have far-reaching effects on coastal ecosystems and their management through light-induced changes in picscivore behavior (Aksnes, 2007). However, visual function of coastal piscivorous fishes has received relatively little attention despite their importance to both commercial and recreational fisheries. We therefore used corneal electroretinography (ERG) to assess the absolute sensitivities, temporal properties and chromatic sensitivities of four piscivores common to coastal waters of the western North Atlantic. Optical conditions in key mid-Atlantic estuaries such as Chesapeake Bay have changed dramatically over the past century due to industrialization, population expansion, eutrophication and sedimentation (Jackson, 2001; Kemp et al., 2005), with unknown consequences for predation, mating and other activities involving vision because so little is known of the visual function of this

Table 1. Species, standard length (SL) and mass of the four piscivorous fishes investigated in this study

\begin{tabular}{lcc}
\hline Species & SL $(\mathrm{mm})$ & Mass $(\mathrm{g})$ \\
\hline Morone saxatilis & $183-358$ & $320-670$ \\
Pomatomus saltatrix & $183-260$ & $55-95$ \\
Rachycentron canadum & $91-388$ & $40-820$ \\
Paralichthys dentatus & $254-510$ & $270-1045$ \\
\hline
\end{tabular}

estuary's diverse fish fauna. A previous investigation of fish visual ecophysiology (Horodysky et al., 2008) applied comparative methods to assess the visual function in five phylogenetically related fishes that use different optical microhabitats in Chesapeake Bay. Using the same experimental setup and methods, we investigated the converse question, assessing the visual systems of four coastal western North Atlantic piscivores with different phylogenies that use similar microhabitats, bear similar trophic ecologies, or both (Fig. 1). We sought mechanistic insights into how biotic and abiotic processes influence relationships between form, function and the environment in the visual systems of coastal marine fishes.

\section{MATERIALS AND METHODS}

Striped bass (Morone saxatilis Walbaum 1792), bluefish (Pomatomus saltatrix Linnaeus 1766), summer flounder (Paralichthys dentatus Linnaeus 1766) and cobia (Rachycentron canadum Linnaeus 1766) were all captured by standard hook and line fishing gear (Table 1). Animals were maintained in recirculating 18551 aquaria on natural ambient photoperiods at $20 \pm 1^{\circ} \mathrm{C}$ (winter) or $25 \pm 2^{\circ} \mathrm{C}$ (summer). Fish were fed a combination of frozen Atlantic menhaden (Brevoortia tyrannus), squid (Loligo sp.) and commercially prepared food (AquaTox flakes; Zeigler, Gardners, PA, USA).

Experimental and animal care protocols were approved by the College of William \& Mary Institutional Animal Care and Use Committee (protocol no. 0423) and followed all relevant laws of the United States. Fish were removed from holding tanks, sedated with an intramuscular (i.m.) dose of ketamine hydrochloride (Butler Animal Health, Middletown, PA, USA; $30 \mathrm{mg} \mathrm{kg}^{-1}$ ), and immobilized with an i.m. injection of the neuromuscular blocking drug gallamine triethiodide (Flaxedil; Sigma, St Louis, MO, USA; $10 \mathrm{mg} \mathrm{kg}^{-1}$ ). Drugs were re-administered during the course of experiments as required. Following initial drug injections, fish were moved into a light-tight enclosure and placed in a rectangular $800 \mathrm{~mm} \times 325 \mathrm{~mm} \times 180 \mathrm{~mm}$ Plexiglas tank with only a small portion of the head and eye receiving the light stimulus remaining above the water. Subjects were ventilated with filtered and oxygenated sea water $\left(11 \mathrm{~min}^{-1}\right)$ that was temperature controlled $\left(20 \pm 2^{\circ} \mathrm{C}\right)$ to minimize the potentially confounding effects of temperature on ERG recordings (Saszik and Bilotta, 1999; Fritsches et al., 2005). Fish were dark adapted for at least $30 \mathrm{~min}$ prior to any measurements (see Horodysky et al., 2008).

Experiments were conducted during both day and night to control for any circadian rhythms in visual response (McMahon and Barlow, 1992; Cahill and Hasegawa, 1997; Mangel, 2001). We defined 'day' and 'night' following ambient photoperiods. At the conclusion of each experiment, fish were euthanized via a massive overdose $\left(\sim 300 \mathrm{mg} \mathrm{kg}^{-1}\right)$ of sodium pentobarbital (Beuthanasia-D, Schering-Plough Animal Health Corp., Union, NJ, USA).

\section{Electroretinography}

Whole-animal corneal ERGs were conducted to assess the absolute sensitivities, temporal properties and spectral sensitivities. Tefloncoated silver-silver chloride electrodes were used for recording ERGs. The active electrode was placed on the corneal surface and a reference electrode was placed subdermally in the dorsal musculature. ERG recordings and stimulus presentations were controlled using software developed within the LabVIEW system (National Instruments, Austin, TX, USA).

Absolute luminous sensitivities were assessed via intensity-response $(V / \log I)$ experiments described previously (Horodysky et al., 2008). Briefly, six orders of magnitude of stimulus 


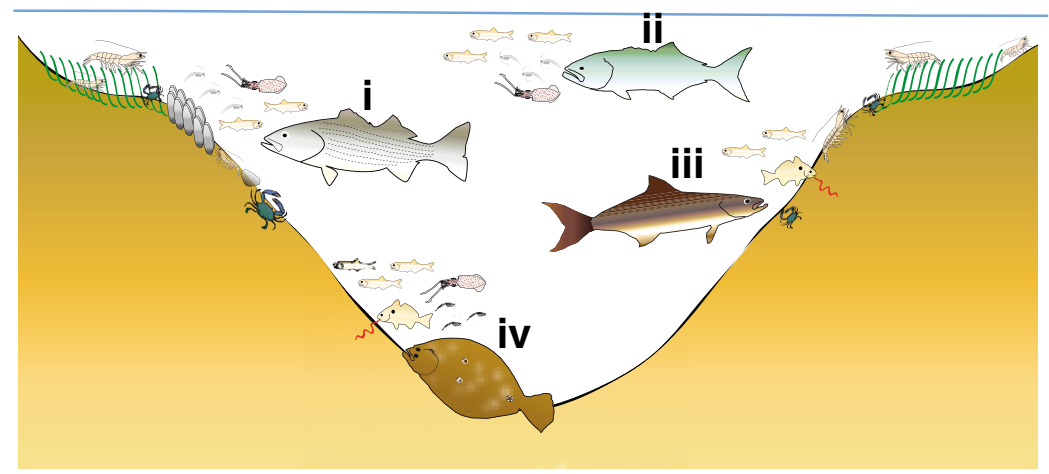

Fig. 1. Conceptual diagram of the microhabitat specialization of the four Chesapeake Bay piscivores examined in this study. Striped bass (i) are schooling anadromous predators of a variety of fishes, crustaceans and soft-bodied invertebrates. Bluefish (ii) are voracious schooling pelagic predators of small fishes, decapods and cephalopods. Cobia (iii) are coastal migrant predators of a myriad of fishes and crustaceans, frequently associating with structures and following large marine vertebrates such as elasmobranchs, seaturtles and marine mammals. Summer flounder (iv) are benthic predators of small fishes, crustaceans and soft-bodied invertebrates. Juveniles of these four species use Chesapeake Bay waters as nursery and foraging grounds; adults are seasonal inhabitants.

intensity were presented to subjects using appropriate combinations of Kodak Wratten 1.0 and 2.0 neutral density filters (Eastman Kodak Co., Rochester, NY, USA) via an Advanced Illumination SL-2420WHI white LED light source that had a working range of roughly three $\log _{10}$ units, and a maximum output intensity of $1585 \mathrm{cdm}^{-2}$. Light intensities were calibrated with a research radiometer (model IL 1700, International Light, Inc., Newburyport, MA, USA). $V / \log I$ experiments progressed from subthreshold to saturation intensity levels in $0.2 \mathrm{log}$ unit steps. At each intensity step, ERG b-waves were recorded from a train of five $200 \mathrm{~ms}$ flashes, each separated by $200 \mathrm{~ms}$ rest periods. This process was repeated three times, recorded and normalized to the maximum voltage response $\left(V_{\max }\right)$. Mean $V / \log I$ curves for each species were created by averaging the $V / \log I$ curves of individuals of that species. Interspecific comparisons of relative luminous sensitivity were made at stimulus irradiances eliciting $50 \%$ of $V_{\max }$ (referred to as $K_{50}$ ). Dynamic ranges, defined as the log irradiance range between the limits of $5-95 \% V_{\max }($ sensu Frank, 2003), were calculated separately for day and night experiments.

The temporal resolution of sciaenid visual systems was assessed via flicker fusion frequency (FFF) experiments using the white light LED source described above and methods developed by Fritsches and colleagues (Fritsches et al., 2005). Sinusoidally modulated white light stimuli ranging in frequency from $1 \mathrm{~Hz}(0 \log$ units) to $100 \mathrm{~Hz}$ ( $2.0 \log$ units) were presented to subjects in $0.2 \log$ unit frequency steps, repeated three times at each frequency, and averaged for each subject. Light stimuli were presented for $5 \mathrm{~s}$, followed by $5 \mathrm{~s}$ of darkness. Seven total FFF experiments were conducted for each subject: one at $25 \%\left(I_{25}\right)$ of maximum stimulus intensity $\left(I_{\max }\right)$ from the $V / \log I$ curve, and one at each $\log _{10}$ step interval over six orders of magnitude of light intensity. A subject's FFF threshold at a given intensity was determined by analyzing the power spectrum of the averaged responses from 1 to $100 \mathrm{~Hz}$ and comparing the power of the subject's response frequency (signal) with the power of a neighboring range of frequencies (noise). Diel and interspecific comparisons were conducted on the FFF data at $I_{\max }$ and $I_{25}$. The FFF at $I_{\max }$ was considered to be the probable maximum FFF attainable by the visual system of a given species, and FFF at $I_{25}$ to be a proxy for ambient environmental light intensity (Horodysky et al., 2008).

Spectral sensitivity experiments were conducted to assess the ability of piscivore visual systems to respond to colored light stimuli that covered the spectral range from UV $(300 \mathrm{~nm})$ to the near infrared $(800 \mathrm{~nm})$ in $10 \mathrm{~nm}$ steps using methods described previously (Horodysky et al., 2008). Briefly, the output of a Cermax Xenon fiberoptic light source (ILC Technology, Sunnydale, CA, USA) was controlled by a CM110 monochromator, collimated, and passed through each of two AB301 filter wheels containing quartz neutral density filters (CVI Laser Spectral Products, Albuquerque, NM, USA). The first wheel allowed light attenuation from 0 to $1 \log$ units of light intensity in $0.2 \log$ unit steps, the second from 0 to $4 \log$ units in $1 \log$ unit steps. In concert, the two wheels allowed the attenuation of light from 0 to $5 \log$ units in $0.2 \log$ unit steps. Stimuli were delivered by a LabVIEW program that controlled a Uniblitz LS6 electronic shutter (Vincent Associates, Rochester, NY, USA) using the analog and digital output of the DAQ card and the computer's serial RS232 interface. Stimuli were presented through a $1 \mathrm{~cm}$ diameter quartz light guide placed within $10 \mathrm{~mm}$ of a subject's eye as five single $40 \mathrm{~ms}$ stimulus flashes at each experimental wavelength, each followed by $6 \mathrm{~s}$ of darkness. The amplitudes of ERG responses were recorded and averaged to form raw spectral response curves for each individual. A spectral $V / \log I$ recording was subsequently conducted for each subject at the wavelength $\left(\lambda_{\max }\right)$ that generated its maximum ERG response $\left(V_{\max }\right)$, which allowed the subsequent calculation of the subject's spectral sensitivity curve. Spectral $V / \log I$ experiments exposed the subject to five individual monochromatic $200 \mathrm{~ms}$ flashes at each intensity, increasing in $0.2 \mathrm{log}$ unit increments over five orders of magnitude. To transform spectral response voltages to spectral sensitivities for each subject, the former were converted to equivalent intensities and were expressed on a percentage scale, with $100 \%$ indicating maximum sensitivity, following Eqn 1:

$$
S=100 \times 10^{-\left|I_{\max }-I_{n}\right|},
$$

where $S$ is the spectral sensitivity, $I_{\max }$ is the intensity at maximum response voltage and $I_{n}$ is the intensity at response voltage $n$. Final spectral sensitivity curves for each species were obtained by averaging the sensitivity curves of all subjects and normalizing to the maximum resulting value so that maximum sensitivity equaled $100 \%$.

\section{Data analyses \\ $V / l o g /$ and FFF}

Piscivore $V / \log I$ and FFF data were analyzed separately using twoway repeated measures ANOVA with Tukey's post hoc comparisons to assess whether ERG responses varied among the four species and between photoperiods. All statistical analyses were conducted using SAS v 9.1 (SAS Institute, Cary, NC, USA). A general model for these analyses is given in Eqn 2:

$$
Y_{i j k}=\mu+\alpha_{i}+\beta_{j}+\delta_{k}+\varepsilon_{i j k},
$$

where $Y_{i j k}$ is the value of the response variable (response) for the $i$ th species, the $j$ th diel period, and the $k$ th level of their interaction, $\mu$ is the overall mean of threshold for all combinations of species and diel periods, $\alpha_{i}$ is the species (fixed factor), $\beta_{j}$ is the diel period (fixed factor), $\delta_{k}$ is the species-diel interaction and $\varepsilon_{i j k}$ is the random 
error term associated with the observation at each combination of the $i$ th species, the $j$ th diel period and the $k$ th level of their interaction.

\section{Spectral sensitivity}

Intraspecific diel differences in spectral sensitivity curves were assessed by subtracting the day and night curves and calculating confidence intervals $(\mathrm{CI})$ of the resulting difference curve. In this analysis, positive values corresponded to increased day sensitivity; negative values indicated increased nocturnal sensitivity. Significant differences in spectral sensitivity were defined where the mean $\pm \mathrm{CI}$ of difference curves did not encompass zero.

To form hypotheses regarding the number and spectral distribution of pigments potentially contributing to piscivore spectral ERG responses, we fitted the SSH (Stavenga et al., 1993) and GFRKD (Govardovkii et al., 2000) vitamin A1 rhodopsin absorbance templates separately to the photopic spectral sensitivity data (Horodysky et al., 2008). A range of possible conditions was considered: $1-3 \alpha$-band rhodopsins, $1-3 \alpha$-band rhodopsins with a single $\beta$-band on any pigment, and $1-3 \alpha$-band rhodopsins with multiple $\beta$-bands. For a given species, condition and template, models of summed curves were created by adding the products of pigment-specific templates and their respective weighting factors. Estimates of the unknown model parameters ( $\lambda_{\max }$ values and their respective weighting proportions) were derived by fitting the summed curves to the ERG data using maximum likelihood.

For each species, we objectively selected the appropriate template (SSH or GFRKD) and number of contributing pigments using an Information Theoretic approach (Burnham and Anderson, 2002) following Akaike's Information Criterion (AIC):

$$
\mathrm{AIC}=-2 \ln (\hat{L})+2 p,
$$

where $\hat{L}$ is the estimated value of the likelihood function at its maximum and $p$ is the number of estimated parameters. All parameter optimization, template fitting and model selection were conducted using the software package $R$ version 2.7 .1 (R Development Core Team 2008, Vienna, Austria).

\section{RESULTS}

White light-evoked ERG b-wave responses of the four piscivores increased non-monotonically with stimulus intensity to maximum amplitudes $\left(V_{\max }\right)$ of $30-400 \mu \mathrm{V}$, then decreased at intensities above those at $V_{\max }$ (Fig.2), presumably due to photoreceptor saturation and a lack of pigment regeneration. The $K_{50}$ values of $V / \log I$ curves differed significantly among species $\left(F_{3,16}=18.83, P<0.0001\right)$ and between diel periods $\left(F_{1,16}=44.23, P<0.0001\right)$. The interaction between species and diel period was also significant because of diel differences in $K_{50}$ values of pelagic piscivores but not for benthic summer flounder $\left(F_{1,16}=11.18, P<0.0003\right)$. Tukey's post-hoc comparisons revealed that the mean photopic $K_{50}$ values of summer flounder were significantly left-shifted $(0.5-1.8 \log$ units, $P<0.05)$ relative to the other piscivores, indicating higher sensitivity to dim light. Mean photopic dynamic ranges of the four species, defined as $5-95 \%$ of $V_{\max }$, varied between 1.84 and $3.35 \mathrm{log}$ units and scotopic dynamic ranges between 2.34 and $3.32 \mathrm{log}$ units. Dynamic ranges varied significantly among the species $\left(F_{3,16}=11.18\right.$, $P<0.0003)$ and diel periods $\left(F_{3,16}=36.43, P<0.0001\right)$; however, the significant interaction term $\left(F_{3,16}=6.57, P<0.005\right)$ compromised interpretation. Pelagic piscivores generally had narrower photopic dynamic ranges with varying degrees of diel differences, contrasting with the broader, diel-invariant dynamic range of benthic summer flounder.

Piscivore FFF values (Fig. 3) varied significantly among the four species $\left(F_{3,20}=9.82, P<0.003\right)$, with benthic summer flounder having significantly lower values than pelagic piscivores. FFF increased with increasing intensity (i.e. greater at $I_{\max }$ than at $I_{25}$; $\left.F_{1,67}=75.46 .27, P<0.001\right)$. Likewise, FFF values were significantly higher during the day than at night $\left(F_{1,67}=75.46 .27, P>0.001\right)$. This

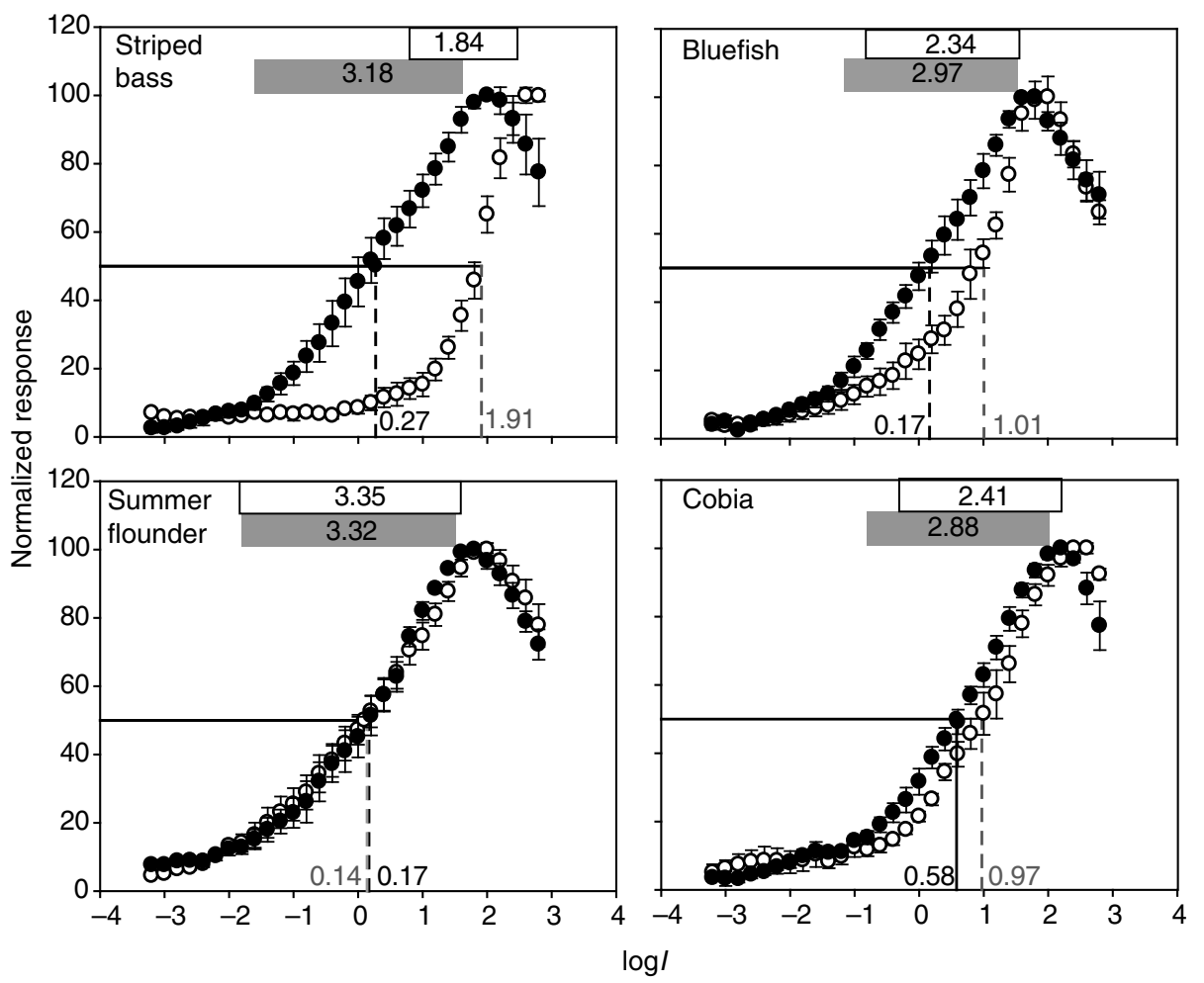

Fig. 2. Intensity-response electroretinograms (ERGs) of striped bass, bluefish, cobia and summer flounder. Each species' intensity response curve is an average from five individuals. Responses were normalized to the maximal response voltage $\left(V_{\max }\right)$ for each individual. Boxes at the top represent each species' dynamic range (5-95\% $\left.V_{\max }\right)$ with numbers indicating its breadth in log intensity units. Dashed vertical lines and adjacent numbers indicate $K_{50}$ points (illumination at $50 \%$ $\left.V_{\max }\right)$. Open symbols, white boxes and gray text represent day experiments; filled symbols, shaded boxes and black text represent night experiments. Light intensities are in log $\mathrm{cd} \mathrm{m}^{-2}$. Error bars are \pm 1 s.e. 

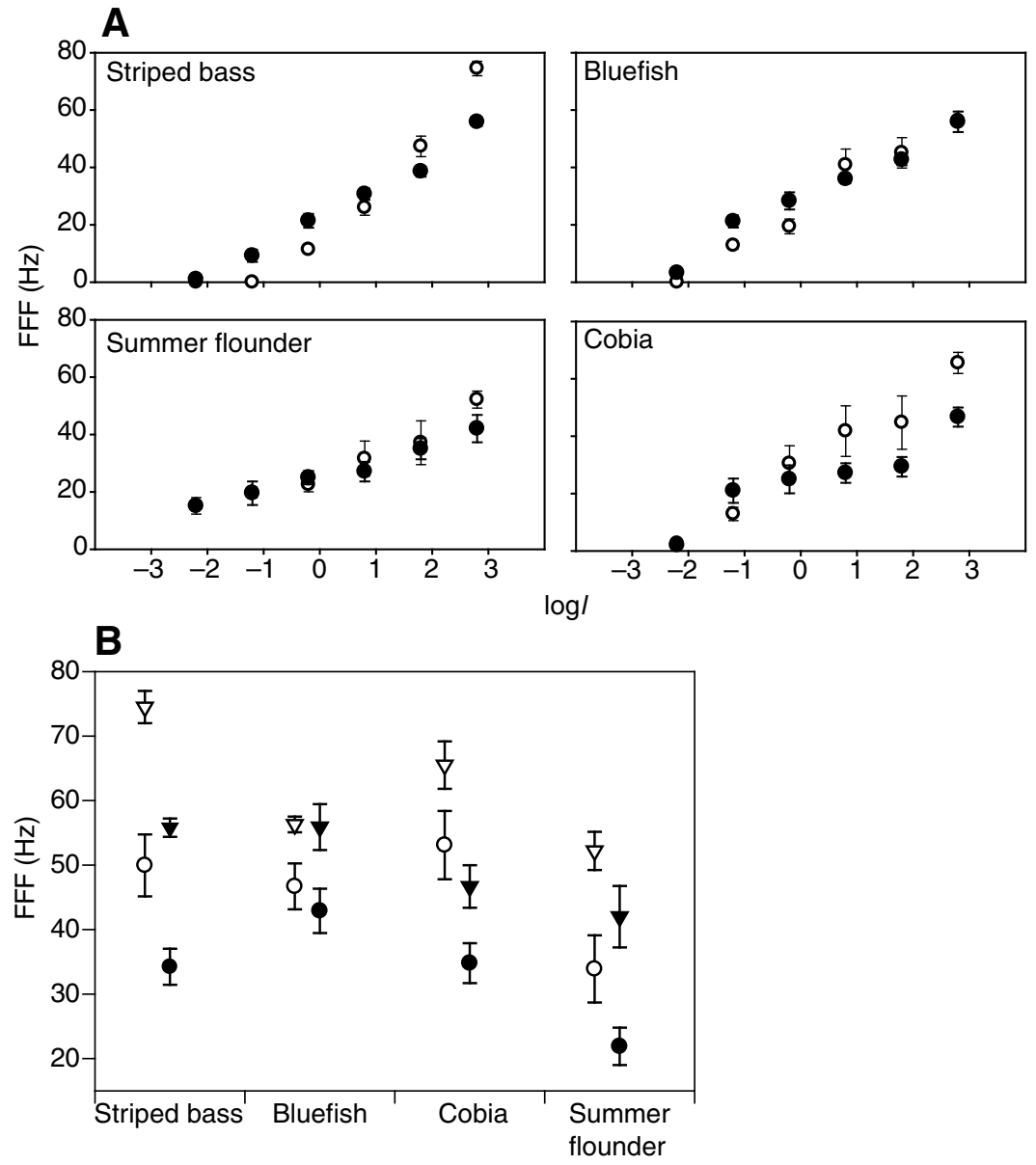

Fig. 3. The relationship between light intensity and flicker fusion frequency (FFF) for striped bass, bluefish, cobia and summer flounder. Open symbols represent day experiments, filled symbols represent night experiments. Error bars are \pm 1 s.e. (A) FFF over six orders of magnitude of light intensity $\left(\log \mathrm{cd} \mathrm{m}^{-2}\right.$ ) for the four Chesapeake Bay piscivores.

(B) Mean FFF values for the four Chesapeake Bay piscivores at $I_{25}$ (light levels $25 \%$ of $I_{\max }$; circles) and $I_{\max }$ (maximum stimulus intensity; triangles). We considered $l_{25}$ to be a proxy for ambient environmental light intensity (sensu Horodysky et al., 2008). difference was most pronounced in cobia and striped bass. Interaction terms were not significant.

Piscivore photopic spectral sensitivities generally spanned 400-600 nm, with cobia having the narrowest spectral range (Fig.4). Striped bass were a clear exception, exhibiting a high sensitivity to longer wavelengths ( $650 \mathrm{~nm}$ and above). Striped bass and bluefish demonstrated a significant nocturnal short wavelength shift, while cobia and summer flounder exhibited no such shifts (Fig. 4).

Given our data, maximum likelihood estimation using published SSH and GFRKD rhodopsin templates suggested that most of the Chesapeake Bay piscivores have multiple pigment mechanisms (Fig. 5). Striped bass (SSH; $\lambda_{\max }=542,612 \mathrm{~nm}$ ) and summer flounder (GFRKD; $\lambda_{\max }=449,524 \mathrm{~nm}$ ) photopic spectral sensitivities were consistent with the presence of two $\alpha$-band vitamin A1 pigments (Table2). In contrast, bluefish were fitted with four rhodopsins (GFRKD; $\lambda_{\max }=433,438,507,547$ ), and the cobia spectral sensitivity curve was fitted by a single rhodopsin ( $\mathrm{SSH}$ ) centered at $501 \mathrm{~nm}$.

\section{DISCUSSION}

The number, properties and distribution of photoreceptor cells in fish visual systems, their luminous sensitivities, chromatic sensitivities and photopigments, and correlations to the photic properties of habitats have received rigorous attention in the literature (McFarland and Munz, 1975; Dartnall, 1975; Levine and MacNichol, 1979; Bowmaker, 1990; Parkyn and Hawryshyn, 2000). The functional characteristics of the visual systems of fishes generally reflect the aquatic light fields they inhabit, within ecological and phylogenetic constraints (Guthrie and Muntz, 1993). Luminous and chromatic sensitivities as well as temporal and spatial properties of fish visual systems are therefore useful metrics to describe the functions and tasks of aquatic visual systems (Lythgoe, 1979; Warrant, 1999; Marshall et al., 2003).

The range of light from which visual information can be obtained is extended in fishes with duplex retinae that use cone cells under photopic (bright) conditions and rod cells during scotopic (dim/dark) conditions (Lythgoe, 1979; Crescitelli, 1991). Piscivore luminous sensitivities, evidenced by the $K_{50}$ points and dynamic ranges of $V / \log I$ curves, are comparable to those of other Chesapeake Bay fishes (Horodysky et al., 2008) and a range of freshwater and marine teleosts (Naka and Rushton, 1966; Kaneko and Tachibana, 1985; Wang and Mangel, 1996; Brill et al., 2008). Coastal and estuarine piscivores demonstrated less luminous sensitivity than deep sea fishes (Warrant, 2000) and mesopelagic arthropods (Frank, 2003). In fact, striped bass, bluefish and cobia, which frequently forage in shallow coastal and estuarine waters, had fairly high $K_{50}$ values $\left(\sim 1-2 \log \mathrm{cd} \mathrm{m}^{-2}\right)$ and very narrow dynamic ranges, similar to those observed in black rockfish (Sebastes melanops), a coastal Pacific sebastid $\left(2.0 \log \mathrm{cd} \mathrm{m}^{-2}\right)$ (Brill et al., 2008). These three pelagic piscivores demonstrated significant diel shifts in luminous sensitivity, presumably as a result of retinomotor movements (Ali, 1975). In daylight, the luminous sensitivities of striped bass, bluefish and cobia were substantially more right-shifted (i.e. less sensitive), with narrower dynamic ranges and larger diel shifts, than those of pelagic- 


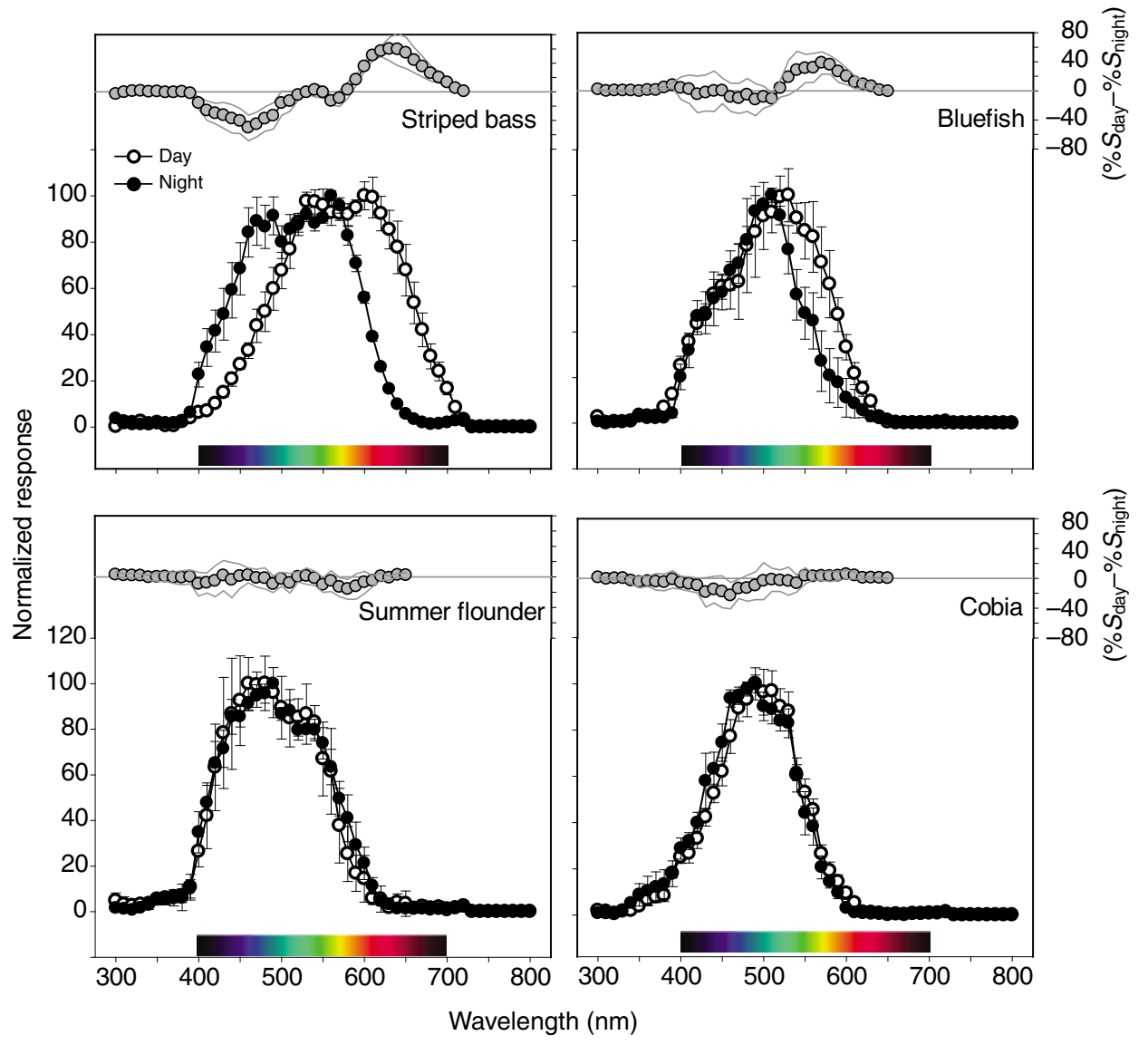

Fig. 4. Spectral sensitivity curves and diel confidence intervals calculated from the ERGs of striped bass, bluefish, cobia and summer flounder for wavelengths of $300-800 \mathrm{~nm}$. Each species' curve is an average from five individuals. Responses at each wavelength were normalized to the wavelength of maximal voltage response $\left(V_{\max }\right)$ for each individual. Open symbols represent day experiments, filled symbols represent night experiments. Error bars are \pm 1 s.e. For each species, the top panels (gray circles, right axes) are the diel differences in spectral ERGs calculated by subtracting the day spectral responses $\left(S_{\text {day }}\right)$ from night responses ( $\left.S_{\text {night }}\right)$. Thin gray lines are $\pm 95 \%$ $\mathrm{Cl}$, calculated as 1.96 (s.e.m). Values above the horizontal zero line (i.e. positive) indicate wavelengths of greater response during daylight; those below the zero line (i.e. negative) indicate wavelengths of greater nocturnal response. Significant diel differences occurred when $\mathrm{Cl}$ did not encompass zero.

foraging sciaenid fishes from the same estuary (Fig. 6) (Horodysky et al., 2008). The $K_{50}$ values of benthic summer flounder $\left(0.14-0.17 \log \mathrm{cd} \mathrm{m}^{-2}\right)$, were similar in magnitude and relative diel invariance to those of demersal Pacific halibut (Hippoglossus stenolepis: $0.14-0.15 \log \mathrm{cd} \mathrm{m}^{-2}$ ) (Brill et al., 2008) and benthic foraging sciaenids $\left(-0.24-0.30 \log \mathrm{cd} \mathrm{m}^{-2}\right)$ (Horodysky et al., 2008) (Fig. 7). The luminous sensitivities of coastal flatfishes, and of other benthic foragers, tend toward the more sensitive end of an emerging continuum for coastal fishes, consistent with their use of low light habitats. In contrast, shallow-dwelling diurnal

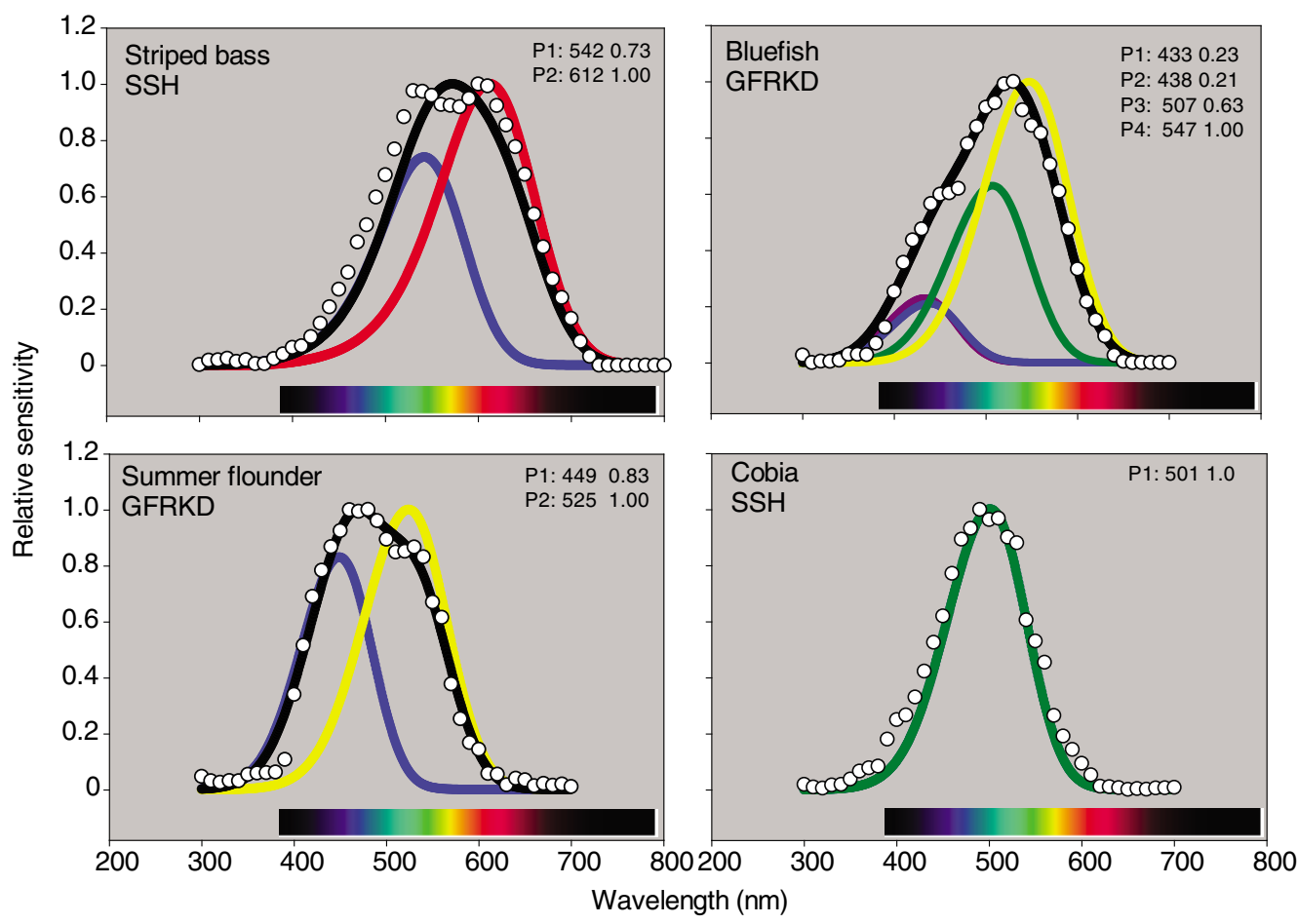

Fig. 5. SSH (Stavenga et al., 1993) and GFRKD (Govardovskii et al., 2000) vitamin A1 templates fitted to piscivore spectral ERG data by maximum likelihood (sensu Horodysky et al., 2008). Only estimates from best fitting models from Table 2 were plotted for each species. Values to the right of each pigment label are estimated $\lambda_{\max }$ and pigment specific weight as estimated by the model. P1 (blue or green) is the short wavelength pigment, P2 (yellow or red) is the intermediate or longer wavelength pigment. Black lines represent additive curves developed by summing the product of each curve weighted by the estimated weighting factor. 
Visual function in piscivores

Table 2. Parameter estimates and model rankings of SSH and GFRKD vitamin A1 rhodopsin templates fitted to piscivore photopic spectral ERG data via maximum likelihood

\begin{tabular}{|c|c|c|c|c|c|c|c|c|c|c|}
\hline Species & Condition & Template & $\lambda_{\max , 1}$ & $\lambda_{\max , 2}$ & $\lambda_{\max , 3}$ & $\lambda_{\max , 4}$ & $-\log (L)$ & $p$ & $\mathrm{AIC}$ & $\Delta \mathrm{AIC}$ \\
\hline \multirow[t]{4}{*}{ Striped bass } & $\mathrm{Di}$ & GFRKD & - & 521 & 611 & - & -112 & 5 & -214 & 7 \\
\hline & & SSH & - & 542 & 612 & - & -115 & 5 & -221 & 0 \\
\hline & & $\mathrm{MSP}^{1}$ & - & 533 & 611 & - & - & - & - & - \\
\hline & & $\mathrm{MSP}^{2}$ & - & 542 & 612 & - & - & - & - & - \\
\hline \multirow[t]{3}{*}{ Bluefish } & Tetra & GFRKD & 433 & 438 & 507 & 547 & -152 & 7 & -286 & 0 \\
\hline & & $\mathrm{SSH}$ & 436 & 503 & 540 & 551 & -148 & 7 & -283 & 3 \\
\hline & & $\mathrm{MSP}^{1}$ & 423 & 447 & 526 & 564 & - & - & - & - \\
\hline \multirow[t]{2}{*}{ Cobia } & Mono & GFRKD & - & 501 & - & - & -69 & 3 & -134 & 11 \\
\hline & & SSH & - & 501 & - & - & -74 & 3 & -145 & 0 \\
\hline \multirow{3}{*}{$\begin{array}{l}\text { Summer } \\
\text { flounder }\end{array}$} & $\mathrm{Di}$ & GFRKD & 449 & 525 & - & - & -88 & 5 & -167 & 0 \\
\hline & & SSH & 451 & 525 & - & - & -82 & 5 & -154 & 13 \\
\hline & & $\mathrm{MSP}^{3}$ & 449 & 524 & - & - & - & - & - & - \\
\hline
\end{tabular}

Vitamin A1 rhodopsin templates: SSH, Stavenga et al., 1993; GFRKD, Govardovskii et al., 2000.

MSP, microspectrophotometry estimates of pigment $\lambda_{\max }$, from the literature ( ${ }^{1} \mathrm{~J}$ ordan and Howe, 2007 ; ${ }^{2}$ Miller and Korenbrot, 1993 ; ${ }^{3}$ Levine and MacNichol, 1979).

$L$, likelihood function; $p$, number of parameters in a model; AIC, Akaike's Information Criterion; Mono, monochromatic; Di, dichromatic; Tetra, tetrachromatic. Only $\alpha$-bands of pigments were considered.

The number following $\lambda_{\text {max }}$ refers to pigment 1 , etc.

Bold type indicates the best-supported pigment and template scenarios based on AIC values (lower is better).

piscivores have lower but more plastic luminous sensitivities, consistent with hunting in extensively variable photic habitats.

Temporal properties of coastal piscivore visual systems are also comparable to those of a range of diurnal freshwater and marine fishes, closely matching species-specific visual requirements and tasks (Warrant, 2004). The FFF of the four piscivores predictably increased with light intensity (sensu Crozier et al., 1938), as was observed in sciaenid fishes (Horodysky et al., 2008). The benthic summer flounder, however, had significantly lower FFF at $I_{25}$ than the three pelagic piscivores, consistent with the use of comparatively deeper and dimmer waters by this flatfish. Daytime FFF at $I_{25}$ ranged little among the three pelagic piscivores $(47-50 \mathrm{~Hz})$, but cobia and bluefish attained these values at intensities $\sim 1$ order of magnitude lower than striped bass, suggesting that the latter may be more lightlimited or may forage on more active prey in clearer waters that the former species. Maximum FFFs, which reveal the scope of the visual system when light is not limiting, were lowest for flounder, intermediate for bluefish and highest for cobia and striped bass. Predators that forage on rapidly swimming prey in clear and bright conditions, such as yellowfin and bigeye tunas (Thunnus albacares and $T$. obesus, respectively), have high FFFs and low spatial summation of photoreceptors [60-100 Hz; evoked potentials (EP) (Bullock et al., 1991); ERGs (Brill et al., 2005)]. In contrast, nocturnal species and those that forage in dim light, such as broadbill swordfish and weakfish (Xiphias gladius and Cynoscion regalis, respectively), have low FFFs and high spatial summation of photoreceptors [ERGs (Fritsches et al., 2005; Horodysky et al., 2008)]. Cobia and striped bass maximum FFF were therefore comparable to those of epipelagic scombrids, those of bluefish were similar to most sciaenids $(\sim 50-60 \mathrm{~Hz})$ and freshwater centrarchid sunfishes $(51-53 \mathrm{~Hz})$, while those of flounder were analogous to crepuscular-foraging weakfish (42 Hz) [ERGs (Crozier et al., 1936; Crozier et al., 1938; Horodysky et al., 2008); EP (Bullock et al., 1991)]. Collectively, maximum FFFs of benthic and nocturnal species in coastal and estuarine waters are lower than those of daytime foraging pelagic species (Figs 6 and 7). We caution that the above metanalysis may be limited by differences in ecosystems as well as experimental and analytical techniques among these many studies, but consider the collective synthesis to be consistent with ecologies of the species discussed.

Chromatic properties of the visual systems of piscivores can likewise be placed in the context of fishes from this and other ecosystems. Coastal fishes are generally sensitive to a shorter subset of wavelengths than many freshwater fishes and a longer range of wavelengths than coral reef, deep sea and oceanic species (Levine and McNichol, 1979; Marshall et al., 2003). For maximum sensitivity in an organism's light microhabitat, scotopic (rod-based) pigment absorption spectra should match the ambient background to optimize photon capture ['Sensitivity Hypothesis' (Bayliss et al., 1936; Clark, 1936)]. Maximal contrast between an object and the visual background is provided by a combination of matched and offset visual pigments ['Contrast Hypothesis' (Lythgoe, 1968)]. Fishes that possess multiple spectrally distinct visual pigments likely use both mechanisms, depending on the optical constraints of their specific light niches (McFarland and Munz, 1975). Western North Atlantic piscivores demonstrated broad, species-specific responses to wavelengths ranging from the blue $(\sim 440 \mathrm{~nm})$ to the yellow-orange $(600-650 \mathrm{~nm})$ end of the spectrum (Fig.4). Responses blue-shifted nocturnally in striped bass and bluefish, whereas cobia and flounder showed no diel shifts. Coastal and estuarine fishes are commonly dichromats possessing short wavelength visual pigments with $\lambda_{\max }$ values ranging from 440 to $460 \mathrm{~nm}$ and intermediate wavelength pigments with $\lambda_{\max }$ values of 520 to $540 \mathrm{~nm}$ (Lythgoe and Partridge, 1991; Lythgoe et al., 1994; Jokela-Määttä et al., 2007; Horodysky et al., 2008).

Chromatic sensitivities of the four piscivores indicate speciesspecific pigment mechanisms based on a comparison of rhodopsin templates fitted to our ERG data and published microspectrophotometry (MSP) estimates of pigment $\lambda_{\max }$ for the species (Table 2). The ERG data of juvenile cobia were consistent with a single rhodopsin pigment. Although it is unclear whether this condition remains throughout ontogeny in the species, monochromacy occurs in other large aquatic predators including cetaceans, phocids and elasmobranchs such as the sandbar shark 


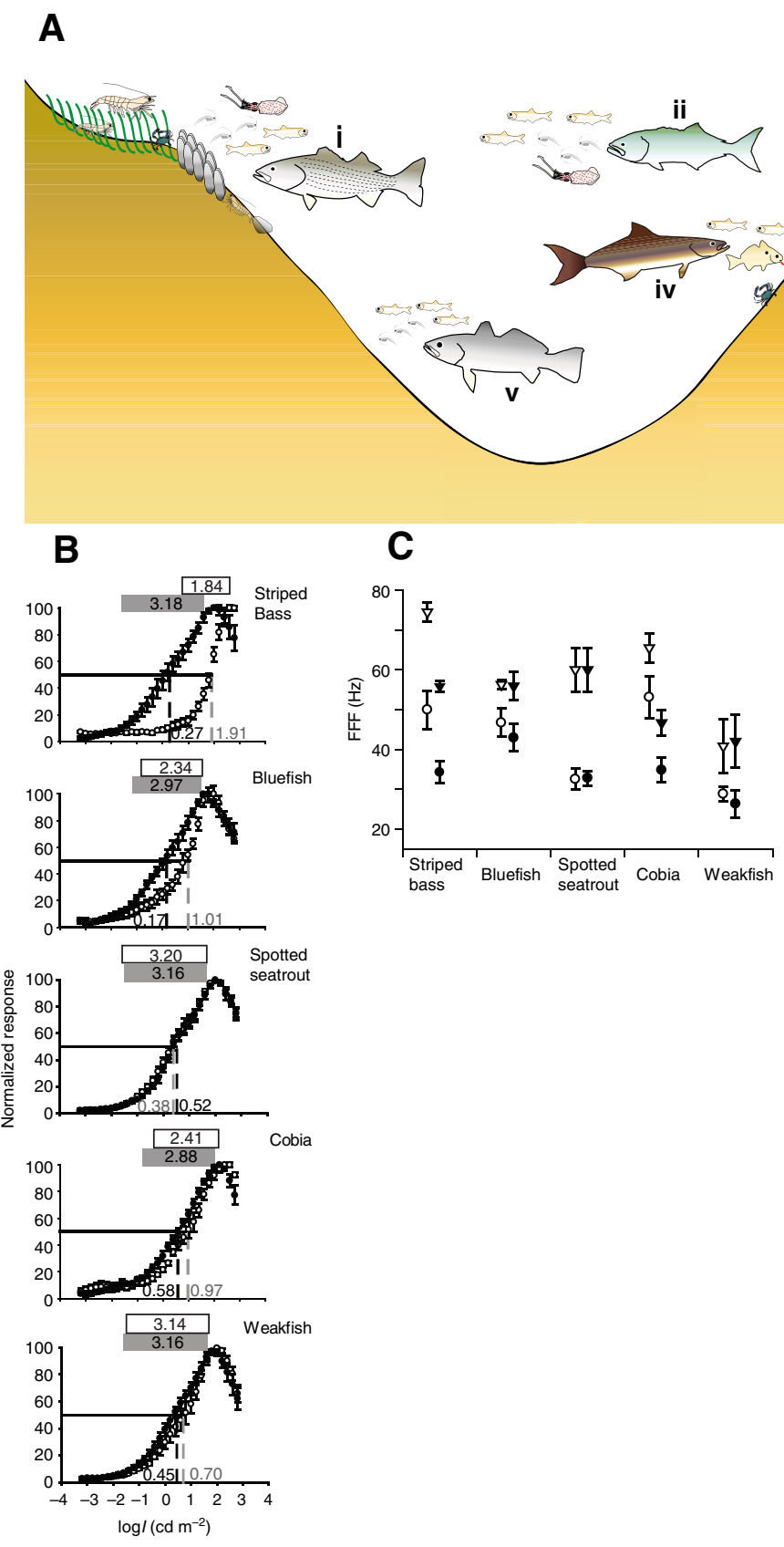

(Peichl et al., 2001; Litherland, 2009). Striped bass and summer flounder appear to have two visual pigments while bluefish appear to have four (Levine and MacNichol, 1979; Miller and Korenbrot, 1993; Jordan and Howe, 2007). Template fitting procedures may not extract the exact $\lambda_{\max }$ values from prior MSP studies due to potential differences in habitats, experimental error in ERG and/or MSP experiments, the generally poor performance of rhodopsin templates at short wavelengths (Govardovskii et al., 2000), or a combination of these factors. ERG is well suited for comparative investigations of vision and form-function relationships in fishes (Ali and Muntz, 1975; Pankhurst and Montgomery, 1989) and measures summed retinal potentials that account for any filtration by ocular media, which MSP does not (Brown, 1968; Ali and Muntz, 1975). Selective isolation of individual mechanisms and behavioral experiments may help determine the functions of multiple cone mechanisms (Barry and Hawryshyn, 1999; Parkyn and Hawryshyn, 2000); however, cone morphologies, their photopigments and
Fig. 6. Comparative visual function of five Chesapeake Bay pelagic predators. Data for striped bass (Ai), bluefish (Aii) and cobia (Avi) are from the present study. Data for spotted seatrout (Aiii) and weakfish (Av) are from a previous study (Horodysky et al., 2008). For all panels, open symbols are results of day experiments, filled symbols are results of night experiments. All error bars indicate \pm 1 s.e.m. (A) Conceptual diagram of the microhabitat specialization of five pelagic piscivores. (B) Intensity-response ERGs of five pelagic predators. Each species' intensity-response curve is an average from at least five individuals. Shaded boxes represent the dynamic range and breadth of each species in $\log \mathrm{cd} \mathrm{m}^{-2}$ : photopic - white boxes and gray text; scotopic - shaded boxes and black text. Dashed vertical lines and adjacent numbers indicate $K_{50}$ points. (C) Mean FFF values for the five pelagic predators. Triangles are the FFF at $I_{\text {max }} ;$ circles are FFF at $I_{25}$, considered to be a proxy for ambient environmental light intensity. (D) Spectral sensitivity curves calculated from the ERGs of the five pelagic predators for wavelengths of $300-800 \mathrm{~nm}$. Responses at each wavelength were normalized to the wavelength of maximum response $\left(V_{\max }\right)$ for each individual.

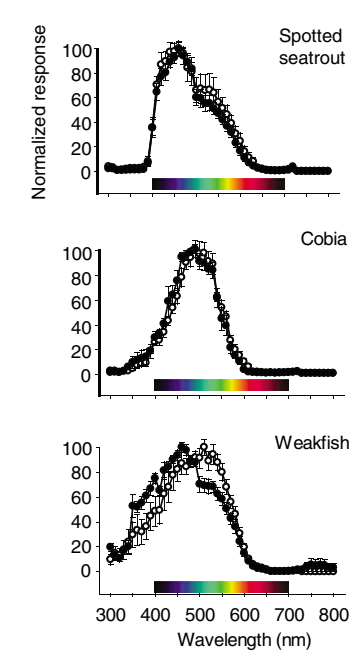

distributions were beyond the scope of our study. Comparison of MSP estimates with those resulting from the rhodopsin template fitting procedures (Horodysky et al., 2008) suggest that the latter provides useful comparative insights into visual systems with few, fairly widely spaced visual pigments. The procedure does, however, risk mischaracterizing $\lambda_{\max }$ in species with many closely spaced pigments and/or when underlying data are sparse and fitting procedures balance optimization and parsimony.

Collectively, the luminous, temporal and chromatic properties of the visual systems of coastal and estuarine fishes are consistent with inferences based on ecology and lifestyle (this study) (Horodysky et al., 2008). The eyes of daytime-active pelagic piscivores, such as striped bass, bluefish and sciaenid spotted seatrout (Horodysky et al., 2008) have fast temporal resolution, limited photopic luminous sensitivity and broadly tuned chromatic sensitivity, consistent with foraging on fast-moving planktivorous fishes in well-lit waters (Fig. 6). Daytime active pelagic piscivores, such as striped bass and 
A

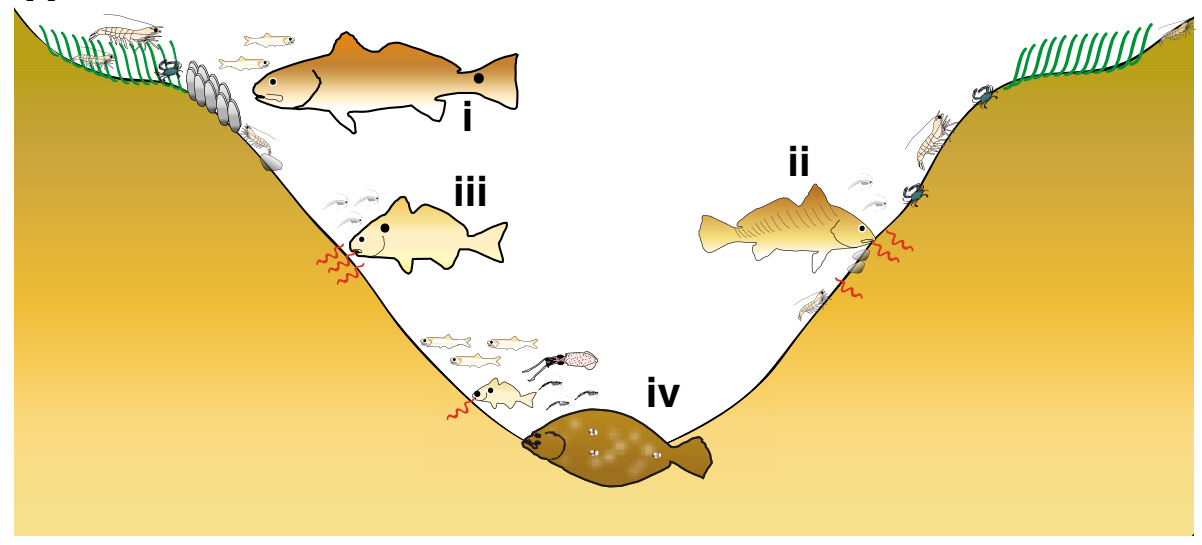

B

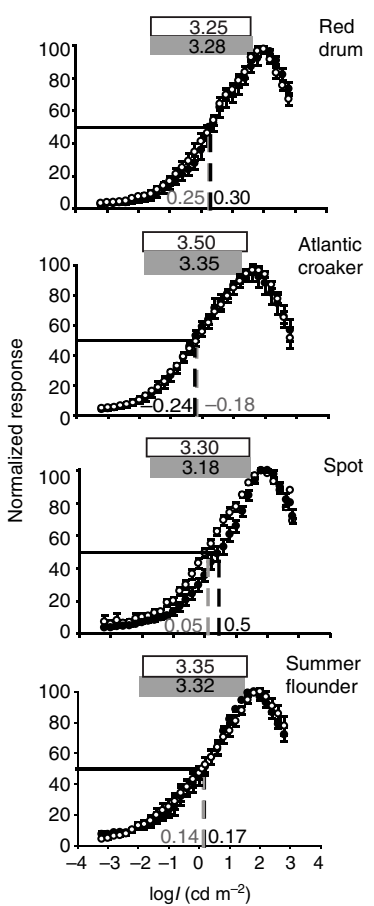

C

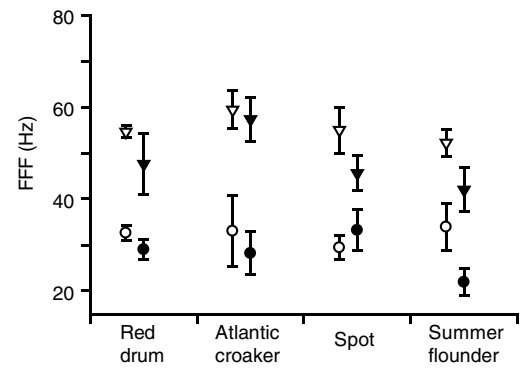

D

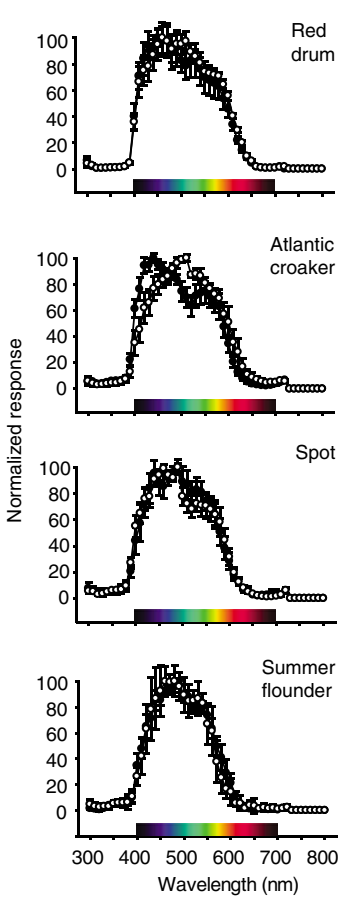

Fig. 7. Visual function of four benthic foragers from Chesapeake Bay. Data for red drum (Ai), Atlantic croaker (Aii) and spot (Aiii) are from a previous study (Horodysky et al., 2008). Data for summer flounder (Aiv) are from the present study. For all panels, open symbols are results of day experiments, filled symbols are results of night experiments. All error bars indicate \pm 1 s.e.m. (A) Conceptual diagram of the microhabitat specialization of the four benthic predators. (B) Intensity-response ERGs of the four predators. Shaded boxes represent the dynamic range of each species in $\log \mathrm{cd} \mathrm{m}^{-2}$ : photopic white boxes and gray text; scotopic shaded boxes and black text. Dashed vertical lines and adjacent numbers indicate $K_{50}$ points. (C) Mean FFF values for the four benthic predators. Triangles are the FFF at $I_{\max }$; circles are FFF at $l_{25}$, considered to be a proxy for ambient environmental light intensity. (D) Spectral sensitivity curves calculated from the ERGs of the four benthic predators for wavelengths of $300-800 \mathrm{~nm}$. Responses at each wavelength were normalized to the wavelength of maximum response $\left(V_{\max }\right)$ for each individual. spotted seatrout, enhance resolution at the expense of luminous sensitivity during daylight hours, but increase nocturnal sensitivity, presumably at the expense of acuity, to match their diurnal light niches (Horodysky et al., 2008). In contrast, deeper-dwelling piscivores, such as summer flounder and weakfish, have comparatively slower, more sensitive vision, higher spatial summation and reduced acuity (K. Fritsches, personal communication) (Warrant, 1999; Horodysky et al., 2008). These species exhibit few diurnal differences in visual properties (Figs 6 and 7), presumably because their light niches are consistently dim.

Increasing turbidity asymmetrically affects the distances over which conspecifics, predators and prey interact. For encounter-rate feeders (i.e. many larvae and planktivores), turbidity resuspends forage and may serve as cover, decreasing sighted distances and increasing escape rates from predatory attacks (Utne-Palm, 2002). Benthic foragers are typically well adapted to low-light ambient conditions typical of turbid habitats, and many also feature enhancement of other sensory modalities to increase prey detection (Huber and Rylander, 1992). Conversely, reductions in ambient light intensity and veiling effects impede the ability of lowsensitivity, high-contrast piscivore visual systems to view fastmoving planktivorous prey against strongly turbid backgrounds (De Robertis et al., 2003; Thetmeyer and Kils, 1995; Turesson and Bronmark, 2007). Moderate turbidity may actually improve the contrast of prey against estuarine backgrounds (Utne-Palm, 2002), but the visual systems of striped bass and bluefish require bright light for optimal function and should thus be frequently disadvantaged in coastal habitats rendered highly turbid by human activities. Anthropogenic light pollution in coastal habitats may, however, extend the duration of photopic vision and thus visual foraging via general illumination of the night sky in urbanized areas (sensu Mazur and Beauchamp, 2006), and by constraining nocturnal foraging arenas to small, highly illuminated point sources such as dock and bridge lights. Human impacts may thus be ecologically structuring factors in coastal ecosystems that both benefit and impede visually feeding piscivores, with turbidity further exerting contradictory and asymmetric effects on different trophic levels and life stages (Utne-Palm, 2002). 
Optical conditions in coastal and estuarine waters are complex and have changed dramatically over the past century due to human activities (Kemp et al., 2005), with potentially large consequences for visually foraging piscivores. Characterizing visual function of nearshore fishes is a first step, but many questions remain on topics such as ambient light levels in specific light niches (Marshall et al., 2006) as well as light threshold effects on predator-prey interactions (Mazur and Beauchamp, 2003; De Robertis et al., 2003), reproduction (Engström-Östa and Candolin, 2007), and fishery gear interactions (Buijse et al., 1992). The effects of ambient light fields on the reflectance of conspecifics, prey and competitors, encounter and reaction distances, and the manner in which these change in space and time should also be investigated to gain insight into visual systems and tasks for a species (Levine and MacNichol, 1979; Johnsen, 2002). Comparative approaches investigating the form-function-environment relationships between sensory ecophysiology, behavioral ecology and ecosystem dynamics are thus important to mechanistically link processes from the cellular to the individual to the population level to support better management of aquatic resources.

\section{ACKNOWLEDGEMENTS}

We thank Captain S. Wray, J. Lucy, J. Smith and P. Lynch, and the vessels Bada Bing and Sea Beaver, for their assistance collecting study animals. M. Patterson, $\mathrm{S}$. Johnsen and L. Litherland kindly provided comments on earlier drafts of this manuscript. K. Fritsches and L. Litherland patiently provided assistance with lamp calibrations and electroretinographic experiments, and M. Luckenbach, R. Bonniwell and S. Fate provided logistical assistance and extreme flexibility in support of these experiments. Assistance with animal husbandry was graciously provided by A. Buchheister, P. Lynch, C. Magel, S. Musick, T. Nania, L. Rose and J. Woodward. This research was funded by the Virginia Sportfish Development Fund, Virginia Marine Resources Commission. Partial support was also provided by the National Marine Fisheries Service and by an award to A.Z.H. from the International Women's Fishing Association. E.J.W. is grateful for the ongoing support of the Swedish Research Council (VR). This is VIMS contribution number 3064.

\section{REFERENCES}

Abrahams, M. and Kattenfeld, M. (1997). The role of turbidity as a constraint on predator-prey interactions in aquatic environments. Behav. Ecol. Sociobiol. 40, 169174.

Ali, M. A. (1975). Retinomotor responses. In Vision in Fishes: New Approaches in Research (ed. M. A. Ali), pp. 313-355. New York, NY: Plenum Press.

Ali, M. A. and Muntz, W. R. A. (1975). Electroretinography as a tool for studying fish vision. In Vision in Fishes: New Approaches in Research (ed. M. A. Ali), pp. 159170. New York, NY: Plenum Press.

Aksnes, D. L. (2007). Evidence for visual constraints in large marine fish stocks. Limnol. Oceanogr. 52, 198-203.

Aksnes, D. L. and Utne, A. C. W. (1997). A revised model of visual range in fish. Sarsia 82, 137-147.

Barry, K. L. and Hawryshyn, C. W. (1999). Spectral sensitivity of the Hawaiian saddle wrasse, Thallassoma duperrey, and implications for visually mediated behavior on coral reefs. Environ. Biol. Fishes 56, 429-442.

Bayliss, L. E., Lythgoe, J. N. and Tansley, K. (1936). Some forms of visual purple in sea fishes with a note on the visual cells of origin. Proc. R. Soc. Lond. B. Biol. Sci. 120, 95-114.

Bowers, D. G. and Brubaker, J. M. (2004). Underwater sunlight maxima in the Menai Strait. J. Opt. A: Pure Appl. Opt. 6, 684-689.

Bowmaker, J. K. (1990). Visual pigments of fishes. In The Visual System of Fish (ed. R. H. Douglas and M. B. A. Djamgoz), pp. 82-107. London: Chapman and Hall.

Brown, K. T. (1968). The electroretinogram: its components and origins. Vision Res. 8 , 633-677.

Brill, R. W., Bigelow, K. A., Musyl, M. K., Fritsches, K. A. and Warrant, E. J. (2005). Bigeye tuna (Thunnus obesus) behavior and physiology and their relevance to stock assessments and fishery biology. Col. Vol. Sci. Pap. ICCAT 57, 142-161.

Brill, R. W., Magel, C., Davis, M. W., Hannah, R. W. and Rankin, P. S. (2008). Effects of events accompanying capture (rapid decompression and exposure to bright light) on visual function in black rockfish (Sebastes melanops) and Pacific halibut (Hippoglossus stenolepis). Fish Bull. (Wash. DC) 106, 427-437.

Buijse, A. D., Schaap, L. A. and Bult, T. P. (1992). Influence of water clarity on the catchability of six freshwater fish species in bottom trawls. Can. J. Fish. Aquat. Sci. 49, 885-893.

Bullock, T. H., Hoffmann, M. H., New, J. G. and Nahm, F. K. (1991). Dynamic properties of visual evoked potentials in the tectum of cartilaginous and bony fishes, with neuroethological implications. J. Exp. Zool. Suppl. 5, 142-255.

Burnham, K. P. and Anderson, D. R. (2002). Model Selection and Multimodel Inference: A Practical Information-Theoretic Approach, 488 pp. New York: Springer.
Cahill, G. M. and Hasegawa, M. (1997). Circadian oscillators in vertebrate retina photoreceptor cells. Biol. Signals 6, 191-200.

Carpenter, S. R. and Kitchell, J. F. (1993). The Trophic Cascade in Lakes. New York: Cambridge University Press.

Clark, R. L. (1936). On the depths at which fishes can see. Ecology, 17, 452-456.

Collin, S. P. (1997). Specialisations of the teleost visual system: adaptive diversity from shallow-water to deep-sea. Acta Physiol. Scand. 161, 5-24.

Crescitelli, F. (1991). The scotopic photoreceptors and their visual pigments of fishes: functions and adaptations. Vis. Res. 31, 339-348.

Crozier, W. J., Wolf, E. and Zerrahn-Wolf, G. (1936). On critical frequency and critical illumination for response to flickered light. J. Gen. Physiol. 20, 211-228.

Crozier, W. J., Wolf, E. and Zerrahn-Wolf, G. (1938). Critical illumination and flicker frequency as a function of flash duration: for the sunfish. J. Gen. Physiol. 21, 313334.

Dartnall, H. J. A. (1975). Assessing the fitness of visual pigments for their photic environments. In Vision in Fishes: New Approaches in Research (ed. M. A. Ali), pp. 159-170. New York, NY: Plenum Press.

De Robertis, A., Ryer, C., Veloza, A. and Brodeur, R. D. (2003). Differential effects of turbidity on prey consumption of piscivorous and planktivorous fish. Can. J. Fish. Aquat. Sci. 60, 1517-1526.

Engström-Östa, J. and Candolin, U. (2007). Human-induced water turbidity alters selection on sexual displays in sticklebacks. Behav. Ecol. 18, 393-398.

Frank, T. M. (2003). Effects of light adaptation on the temporal resolution of deep-sea crustaceans. Integr. Comp. Biol. 43, 559-570.

Fritsches, K. A., Brill, R. W. and Warrant, E. J. (2005). Warm eyes provide superior vision in swordfishes. Curr. Biol. 15, 55-58

Gallegos, C. L., Jordan, T. E., Hines, A. H. and Weller, D. E. (2005). Temporal variability of optical propertes in a shallow, eutrophic estuary: seasonal and interannual variability. Estuar. Coast. Shelf Sci. 64, 156-170.

Grecay, P. A. and Targett, T. E. (1996a). Effects of turbidity, light level and prey concentration on feeding of juvenile weakfish Cynoscion regalis. Mar. Ecol. Progr. Ser. 131, 11-16.

Grecay, P. A. and Targett, T. E. (1996b). Spatial patterns in condition and feeding of juvenile weakfish in Delaware Bay. Trans. Am. Fish. Soc. 125, 803-808.

Gregory, R. S. and Northcote, T. G. (1993). Surface, planktonic, and benthic foraging by juvenile Chinook salmon (Oncorhynchus tshawytscha) in turbid laboratory conditionns. Can. J. Fish. Aquat. Sci. 50, 233-240.

Govardovskii, V. I., Fyhrquist, N., Reuter, T., Kuzmin, D. G. and Donner, K. (2000). In search of the visual pigment template. Vis. Neurosci. 17, 509-528.

Guthrie, D. M. and Muntz, W. R. A. (1993). Role of vision in fish behavior. In Behavior of Teleost Fishes, 2nd edn (ed T. P. Pitcher), pp. 89-121. London: Chapman and Hall.

Harding, L. W., Jr (1994). Long-term trends in the distribution of phytoplankton in Chesapeake Bay: roles of light, nutrients and streamflow. Mar. Ecol. Prog. Ser. 104 267-291.

Hart, N. S., Lisney, T. J. and Collin, S. P. (2006). Visual communication in elasmobranchs. In S Communication in Fishes (eds F. Ladich, S. P. Collin, P. Moller and B. G. Kapoor), pp. 337-392. Enfield, NH: Science Publishers.

Hobson, E. S., McFarland, W. N. and Chess, J. R. (1981). Crepuscular and nocturnal activities of Californian nearshore fishes, with consideration of their scotopic visual pigments and the photic environment. Fish Bull. 79, 1-30.

Horodysky, A. Z., Brill, R. W., Warrant, E. J., Musick, J. A. and Latour, R. J. (2008). Comparative visual function in five sciaenid fishes inhabiting Chesapeake Bay. J. Exp. Biol. 211, 3601-3612.

Huber, R. and Rylander, M. K. (1992). Brain morphology and turbidity preference in Notropis and related genera (Cyprinidae, Teleostei). Env. Biol. Fishes 33, 153-165.

Jackson, J. B. C. (2001). What was natural in the coastal oceans. Proc. Natl. Acad. Sci. USA 98, 5411-5418.

Jerlov, N. G. (1968). Optical Oceanography, pp. 4-9. New York: Elsevier.

Johnsen, S. (2002). Cryptic and conspicuous coloration in the pelagic environment. Proc. R. Soc. Lond. B. Biol. Sci. 269, 243-256.

Jokela-Määttä, M., Smura, T., Aaltonen, A. and Ala-Laurila, P. (2007). Visual pigments of Baltic Sea fishes of marine and limnic origin. Vis. Neurosci. 24, 389-398.

Jordan, R. C. and Howe, D. V. (2007). Photopigment spectral absorbance in Four Hudson River fishes. J. Freshw. Ecol. 22, 155-157.

Kaneko, A. and Tachibana, M. (1985). Electrophysiological measurements of the spectral sensitivity of three types of cones in the carp retina. Jpn. J. Physiol. 35, 355-365.

Kemp, W. M., Boynton, W. R., Adolf, J. E., Boesch, D. F., Boicourt, W. C., Brush, G., Cornwell, J. C., Fisher, T. R., Glibert, P. M., Hagy, J. D. et al. (2005). Eutrophication of Chesapeake Bay: historical trends and ecological interactions. Mar. Ecol. Progr. Ser. 303, 1-29.

Levine, J. S. and MacNichol, E. F. (1979). Visual pigments in teleost fishes: effects of habitat, microhabitat, and behavior of visual system evolution. Sens. Proc. 3, 95-131. Loesch, J. G., Kriete, W. H. and Foell, E. J. (1982). Effects of light intensity on the catchability of juvenile anadromous Alosa species. Trans. Am. Fish. Soc. 111, 41-44.

Litherland, L. E. (2009). Neuroethological studies in shark vision. PhD dissertation, University of Queensland, Brisbane, Australia, $211 \mathrm{pp}$.

Lythgoe, J. N. (1968). Visual pigments and visual range underwater. Vis. Res. 8, 9971012.

Lythgoe, J. N. (1975). Problems of seeing colours under water. In Vision in Fishes: New Approaches in Research (ed M. A. Ali), pp. 619-634. New York, NY: Plenum Press.

Lythgoe, J. N. (1979). Ecology of Vision. Oxford: Clarendon Press.

Lythgoe, J. N. (1988). Light and vision in the aquatic environment. In Sensory Biology of Aquatic Animals (ed J. Atema, R. R. Fay, A. N. Popper and W. N. Tavolga), pp. 131-149. New York, NY: Springer-Verlag.

Lythgoe, J. N. and Partridge, J. C. (1991). The modeling of optimal visual pigments of dichromatic teleosts in green coastal waters. Vision Res. 31, 361-371. 
Lythgoe, J. N., Muntz, W. R. A., Partridge, J. C., Shand, J. and Williams, D. M. (1994). The ecology of the visual pigments of snappers (Lutjanidae) on the Great Barrier reef. J. Comp. Physiol. 174, 461-467.

Mangel, S. C. (2001). Circadian clock regulation of neuronal light responses in the vertebrate retina. Prog. Brain Res. 131, 505-518.

Marshall, N. J., Jennings, K., McFarland, W. N., Loew, E. R. and Losey, G. S. (2003). Visual biology of Hawaiian coral reef fishes. III. Environmental light and an integrated approach to the ecology of reef fish vision. Copeia 2003, 467-480.

Marshall, J. M., Vorobyev, M. and Siebeck, U. E. (2006). What does a reef fish see when it sees reef fish? Finding Nemo. In Communication in Fishes (ed. F. Ladich, S. P. Collin, P. Moller and B. G. Kapoor), pp. 393-422. Enfield, NH: Science Publishers.

Mazur, M. M. and Beauchamp, D. A. (2003). A comparison of visual prey detection among species of piscivorous salmonids: effects of light and low turbidities. Env. Biol. Fishes. 67, 397-405.

Mazur, M. M. and Beauchamp, D. A. (2006). Linking piscivory to spatial-temporal distributions of pelagic prey fishes with a visual foraging model. J. Fish. Biol. 69, 151-175.

McFarland, W. N. (1986). Light in the sea: correlations with behaviors of fishes and invertebrates. Am. Zool. 26, 389-401.

McFarland, W. N. and Loew, E. R. (1983). Wave produced changes in underwater light and their relations to vision. Environ. Biol. Fishes. 8, 173-184.

McFarland, W. N. and Munz, F. W. (1975). Part III: the evolution of photopic visual pigments in fishes. Vision Res. 15, 1071-1080.

McMahon, D. G. and Barlow, R. B. (1992). Electroretinograms, eye movements, and circadian rhythms. J. Gen. Physiol. 100, 155-169.

Miller, J. L. and Korenbrot, J. I. (1993). Phototransduction and adaptation in rods, single cones, and twin cones of the striped bass retina: a comparative study. Vis. Neurosci. 10, 653-657.

Naka, K. I. and Rushton, W. A. H. (1966). S-potentials from colour units in the retina of fish (Cyprinidae). J. Physiol. 185, 536-555.

Northcote, T. G. (1988). Fish in the structure and function of freshwater ecosystems: a 'top down' view. Can. J. Fish. Aquat. Sci. 45, 361-379.

Paine, R. T. (1966). Food web complexity and species diversity. Am. Nat. 100, 65-75.

Pankhurst, N. W. and Mongomery, J. C. (1989). Visual function in four Antarctic nototheniid fishes. J. Exp. Biol. 142, 311-324.

Parkyn, D. C. and Hawryshyn, C. W. (2000). Spectral and ultraviolet-polarization sensitivity in juvenile salmonids: a comparative analysis using electrophysiology. J. Exp. Biol. 203, 1173-1191.
Peichl, L., Berhmann, G. and Kroger, R. (2001). For whales and seals the ocean is not blue: a visual pigment loss in marine mammals. Eur. J. Neurosci. 13, 1520-1528.

Rowland, W. J. (1999). Studying visual cues in fish behavior: a review of ethological techniques. Environ. Biol. Fishes. 56, 285-305.

Saszik, S. and Bilotta, J. (1999). The effects of temperature on the dark-adapted spectral sensitivity function of the adult zebrafish. Vision Res. 39, 1051-1058.

Schubert, H., Sagert, S. and Forster, R. M. (2001). Evaluation of the different levels of variability in the underwater light field of a shallow estuary. Helgol. Mar. Res. 55, $12-22$

Seehausen, O., van Alphen, J. J. M. and Witte, F. (1997). Cichlid fish diversity threatened by eutrophication that curbs sexual selection. Science 277, 1808-1811.

Siebeck, U. E., Losey, G. S. and Marshall, J. (2006). UV communication in fish. In Communication in Fishes (ed. F. Ladich, S. P. Collin, P. Moller and B. G. Kapoor), pp. 337-392. Enfield, NH: Science Publishers.

Stavenga, D. G., Smits, R. P. and Hoenders, B. J. (1993). Simple exponential functions describing the absorbance bands of visual pigment spectra. Vision Res. 33, $1011-1017$.

Thetmeyer, H. and Kils, U. (1995). To see and not be seen - the visibility of predator and prey with respect to feeding behavior. Mar. Ecol. Prog. Ser. 126, 1-8.

Turesson, H. and Brönmark, C. (2007). Predator-prey encounter rates in freshwater piscivores: effects of prey density and water transparency. Oecologia. 152, 281-290.

Utne-Palm, A. C. (2002). Visual feeding of fish in a turbid environment: physical and behavioural aspects. Mar. Freshwater Behav. Physiol. 35, 111-128.

Vogel, J. L. and Beauchamp. D. A. (1999). Effects of light, prey size, and turbidity on reaction distances of lake trout (Salvelinus namaycush) to salmonid prey. Can. $J$. Fish. Aquat. Sci. 56, 1293-1297.

Walsh, S. J. (1991). Diel variation in availability and vulnerability of fish to a survey trawl. J. Appl. Ichthyol. 7, 147-159.

Wang, Y. and Mangel, S. C. (1996). A circadian clock regulates rod and cone input to fish retinal cone horizontal cells. Proc. Natl. Acad. Sci. USA. 93, 4655-4660.

Warrant, E. J. (1999). Seeing better at night: life style, eye design, and the optimum strategy of spatial and temporal summation. Vis. Res. 39, 1611-1630.

Warrant, E. J. (2000). The eyes of deep-sea fishes and the changing nature of visual scenes with depth. Proc. R. Soc. Lond. B. Biol. Sci. 355, 1155-1159.

Warrant, E. J. (2004). Vision in the dimmest habitats on Earth. J. Comp. Physiol. A 190, 765-789.

Wing, S. R., Leichter, J. J. and Denny, M. W. (1993). A dynamic model for waveinduced light fluctuations in a kelp forest. Limnol. Oceanogr. 38, 396-407. 